\title{
Border Lives: Prostitute Women in Tijuana
}

by

Debra A. Castillo

María Gudelia Rangel Gómez

and

Bonnie Delgado

BU-1348-MA 
revised 11/96

BU-1348-MA

Border Lives: Prostitute Women in Tijuana ${ }^{1}$

A few years ago, Lynn Sharon Chancer published an article which began by asking the reader to imagine the hypothetical existence of a sociologist involved in participant observer field work on prostitution in Chicago. The theoretical grounding of this article rests upon the readers' and the audience's shared perception about impossibility, or at least, the extreme ambivalence of reception, attending such a project within the U.S. academic setting. As Chancer notes, the responses she received to her suggested scenario lead her to conclude that "something about sex work is especially threatening, putting the researcher socially/sociologically at risk above and beyond the dangers attaching to the researched activity itself"'(Chancer 1993, 167). This perception of a risk that is both personal (participant observation with sex workers is frequently dangerous because of the social spaces in which these women work) and professional (Chancer's comment that colleagues, when approached about this hypothetical project, all asked her in confidence if she had once been a prostitute), leads to a paradoxical positioning on the part of the researcher which undermines her work on at least two levels. The highly charged social connotations of this kind of study tend to identify the researcher as a member of that stigmatized community, to her professional detriment. Of even greater concern is the degree to which the work itself is compromised. More intensely, perhaps, than in other participant observer situations, the academic researcher has an important stake in maintaining a distance between herself and the women who are the objects of her study, to the degree that "the benefits of 
participant observation are seldom brought to bear" (Chancer 1993, 153). This is true of both the researcher, who needs to separate herself from the women, and of the women themselves, whose difficult lives have taught them distrust of strangers who may only want to use them. ${ }^{2}$

Chancer's observations serve as important cautionary reminders in the study that follows, a collaborative work between a public health researcher, a social activist, and a literary critic on prostitutes in Tijuana, Mexico. Experience in Mexico shows that the first reaction of people working in prostitution when approached by researchers is to ask, "Why are you interested in us? Do you have AIDS?" If they are not satisfied with the answer to these questions, they will not participate in the interviews and will influence companions not to participate. Published research in Mexico, as elsewhere, frequently marks the difficulty of securing useful material: commercial sex workers are "reluctant to talk about their trade--especially to outsiders identified with public institutions" (Zalduondo 1991, 167), and researchers often have to adjudicate on the accuracy of the information gathered; as one research article puts it delicately when referring to the veracity of a particular statement, "doubt exists" (Uribe-Salas 1996, 124).

This article derives from ongoing work with both male and female prostitutes, primarily in the areas of education and public health policy. In addition to published research, information for this study came from a two-phase qualitative project. The first phase involved ethnographic work in 1988, including visits to all the different zones of Tijuana in which prostitution is practiced in order to obtain as complete as possible of a list of places in which prostitution occurs, and to learn the social characteristics and study the dynamics of each of these places. This phase of the project included interviews with 184 women working in prostitution in Tijuana with the principle goal of evaluating their knowledge HIV/AIDS and to take blood samples to test prevalence of seropositivity. The second phase of this project took place in 1994-95, and consisted of thirty indepth interviews with prostitutes, made either in their workplaces or in municipal medical clinics; material drawn from these in-depth interviews serves as the basis for the comments that follow. ${ }^{3}$ 
While we too could say "doubt exists" about our focus and our data, we hope that paper will supplement the theoretical picture drawn by Chancer with respect to the ambivalence about serious sociological study of prostitution in the U.S. academy, and also contribute towards an interdisciplinary conversation about the social construction of prostitution in the specific border city of Tijuana, Mexico. In the latter respect we also respond to a call by Uribe et al. for more multidisciplinary study of prostitution in Mexico: "son pocas las investigaciones publicadas que pueden contribuir a ampliar el conocimiento sobre los grupos que ejercen la prostitución; también son limitados los trabajos con enfoques multidisciplinarios que manejen el fenómeno desde la perspectiva epidemiológica, biomédica, etnográfica, antropológica, socioeconómica o cultural" 'there is little published research that can contribute to expanding knowledge about the groups engaged in prostitution; there is also limited work with an interdisciplinary focus which deals with the phenomenon from an epidemiological, biomedical, ethnographic, anthropological, socioeconomic, or cultural perspective' (Uribe et al. 1996, 185).

Discussions about sex workers in Mexico range from historical studies like those of González Rodríguez (1989) or Xorge del Campo (1974), to published memoirs or testimonios of women who worked in prostitution such as Muñuzuri's Memorias de la Bandida (1967) and Antonia Mora's De oficio (1972), to studies of attitudes towards prostitution and of the relationship between prostitution and society by culture critics like Carlos Monsiváis $(1977,1981)$ and José Joaquín Blanco (1981). ${ }^{4}$ In addition to these types of popular-culture materials on prostitution, there is also a body of professional studies on women who work in "el ambiente" in Mexico. Current studies in this field tend to one of four types: historical, sociological, medical, and legal. Uribe et al. find that investigators associated with the area of public health have greater and more reliable access to women working in prostitution in Mexico than people in other academic specialities, thus ameliorating the kind of distrust between sex workers and academic investigators Chancer and Chapkis, among others, point to as a persistent problem in this kind of 
research. At the same time, while we support the Mexican researchers' recommendation that research ties with public health and with NGOs be strengthened (Uribe et al. 1996, 201)--and despite our own commitment to public health concerns--we recognize that often such a focus tends to circumscribe research questions far too narrowly to issues of reproductive health and epidemiological concerns. One currently popular research topic has been studying the relationship between the behavior of the prostitute and the propagation of venereal diseases, and particularly AIDS. Thus, for example, Juárez-Figueroa et al's article, "Prevalencia de anticuerpos contra Pneumocystis carinii en sujetos con prácticas de alto riesgo de SIDA" ('The Prevalence of Antibodies against Pneumocystis carinii in Subjects at a High Risk of AIDS' 1993), and UribeSalas et al.'s "Prevalence, Incidence, and Determinants of Syphilis in Female Commercial Sex Workers in Mexico City" (1996) have an essentially tangential connection to sex workers in Mexico, basically limiting the objectives of the study to providing epidemiologically-oriented information about this disease of use to policy makers in public health.

Because of the concern about AIDS, there has been increased interest in the scientific community in looking at the relationship between prostitution and infection, both as a topic of investigation on the part of health authorities as well as a response to a generalized concern in the society as a whole. However, one of the most important limiting factors of this research is that it does not take into account the social phenomenon of prostitution when it defines the object of study. While much valuable information has been gained, the focus of the research in effect skews the results by reducing the study of the sex worker to a risk category and imagining her work in terms of a site of infection. Valerie Sacks' review of Western literature notes that similar studies done in the U.S. and Europe routinely assume a link between HIV and prostitution, despite consistent evidence that the rate of HIV infection in sex workers is no higher than that among non-prostitute women, with the notable exception of women with a history of IV-drug use (Sacks 1996, 61). Pheterson, too, complains of this bias, citing one study among many: "The 
authors are cognizant of the 'peculiar methodological problems' of research related to prostitution. ... And yet they do not question whethr the status 'prostitute' is indeed the variable under study" (Pheterson 1990, 403). Inevitably, we are lead to the conclusion that epidemiological study of AIDS is as much about inherited prejudices as it is about disease transmission. Such work evokes and participates in a long tradition in middle-class culture of associating sex workers with the femme fatale stereotype, and of stigmatizing female sexuality as contaminated. Bersani reminds us that such cultural phenomena "'legitimate' a fantasy of female sexuality as intrinsically diseased; and promiscuity in this fantasy, far from merely increasing the risk of infection, is the sign of infection" (Bersani 1998, 211). According to this model of promiscuity as the linguistic/scientific sign of infection, a model indexed implicitly in works that begin from the premise that prostitution is a risk category, sexually-transmitted diseases like AIDS are diseases marked as and associated with the female, and transmitted via her unrestrained and unnatural sexual activity to innocent male victims.

Furthermore, like Chancer, we found neither the historical nor the social and legal studies seem to provide the grounding we needed to answer the fundamental questions we wanted to ask about the integration of prostitute women into their communities. Even worse, the material is spotty and incomplete, plagued with evidence of the researcher's pre-existing stereotypes and the prostitute's distrust. Mexican scholars have frequently tended to fill these theoretical and empirical gaps in knowledge with historical surveys and large chunks of paraphrased material from authors as diverse as Carlos Fuentes, Susan Sontag, and Simone de Beauvoir (see, for example, Poniatowska 1988 or Careaga 1990; 98, 108-111), supplementing them with postscripts indicating the relevance of such discussions to a Mexican social model. The result in studies of this sort is a somewhat vague and unfocused essay style that depends for its effect on dubious analogies, on shock value and self-analysis, as well as on the empirical evidence of a database constructed from a very few, often ambiguous questions asked of an inadequate sample of the population. 
Most strikingly, in typical middle-class parlance, the category of "womanhood" is decoupled from the adjectives "evil" or "decent" to hover unambiguously over only a certain type of female behavior, pushing other female persons into a discursive abyss. Note for example this interview in a book by Roberto Martínez Baños, Patricia Trejo de Zepeda, and Edilberto Soto Angli in which freedom of sexual expression is immediately translated by the middle class women interviewed into a de facto definition of prostitution, one which presupposes that sexual freedom is incompatible with womanhood itself. The interviewees further describe the essential characteristic of the prostitute not as the exchange of sex for money, but as an immoral and degenerate enjoyment of sexual relations:

Corazón: Yo conozco a muchas muchachas que salen con uno tres días y al cuarto, a la cama. Y esto pienso que es negativo porque esa mujer ya no es mujer; ya es otra cosa, ya es una mujer que se vende: para mí es una prostituta, es una mujer de la calle.

Patricia: Si por puro placer, sin sentir amor, se acuestan con el primero que se encuentren, pues, realmente sí, son prostitutas.

Corazón: Y está peor, porque ni le pagan. (Martínez Baños et al. 1973, 91)

Corazón: I know a lot of girls who go out with a guy for three days and on the fourth, to bed. And I think this is negative because that woman is no longer a woman; she becomes something else, she becomes a woman who sells herself: for me she's a prostitute, a streetwalker.

Patricia: If they go to bed with the first guy they meet just for pure pleasure, without love, then, well, yes, they really are prostitutes.

Corazón: And it's worse, because they aren't even getting paid. 
It is not just that this exchange manifests an internalization of the traditional double standard by which women are divided into two camps: decent and evil, but that those female human beings who refuse to fit easily into either category are stripped of womanhood itself. For Patricia and Corazón, "woman" is defined not only in opposition to "man", but also in contradistinction to that other-gendered being, the whore. In their conversation, Corazón and Patricia echo the famously elliptical phrase of Federico Gamboa, referring to his prostituteprotagonist, Santa, "¡No era mujer, no; era una ...!" ‘She was not a woman, no, she was a ...' (Gamboa 1903, 15). Curiously, the interviewed women find their counterparts even more morally reprehensible if they do not participate in the single most traditional definition of the prostitute--the exchange of sex for money. Thus, the sexually-liberated woman poses a particular threat to society if she has sex for pleasure; since a traditional reading of this social formation posits a decent woman indifferent to sex, then the prostitute who accepts money for an unpleasant service in which she finds no pleasure fits more readily into the social norm.

One of the frustrations in rereading existing material is that it inevitably returns us to the consolidation of stereotypes such as these. Alternative constructions of femininity--whether authored by women or men of whatever class background--resolve into verbal evocations projected against this pre-existing backdrop, at best pointing to ongoing struggles in popular culture about gender right. In any case, the social phenomenon of prostitution, and the lives of women involved in sex work, are perceived as liminal to the larger social context. The paucity of serious meditations on the personal contexts and social constructions of sex work is particularly ironic in places like Tijuana, in which the conjunction of geographic and moral marginality has always been tightly linked. Because of the "Black Legend" of Tijuana's development as an outpost of Mexican culture and as a gigantic brothel at the service of the USA, its population growth as well as in its economic development have gone hand-in-hand with activities that are stigmatized or prohibited in other places, and in Tijuana the tight imbrication of (provincial) 
identity and (deviant) female sexuality is particularly pronounced. Tijuana's infamous international image as a meat market for the United States--U.S. men cross the border to purchase sex from Mexican women, while Mexican men cross the border to sell their labor in U.S. fields--suggests that from both central Mexico as well as the U.S. there arises a tendency to feminize Tijuana in a particularly marginalizing and stigmatized manner. One result of this process is a generalized conception of the city as feminized; it is variously described as a "generous lady" who allows a better standard of living to her inhabitants, as a "frivolous young woman" who attracts men only to cause them to "lose their souls" and finally, as a "decadent and grotesque prostitute" who abuses those unfortunate souls who pass through Tijuana in either direction. Tijuana, in this respect, confirms the primacy of centrist notions about the provinces as unattractive at best, and degraded at worst. Even more curiously, in view of Tijuana's notorious representation through an image of un-domestic femininity, until very recently, whether because of or despite the stereotype, writers and social scientists have tended to avoid analysis of the actual women who work in the night clubs as waitresses, dancers for pay, strip teasers, and prostitutes. As Patricia Barrón Salido acutely comments, even in respected studies of marginal figures from Tijuana, "parecería que la prostitución queda entre puntos suspensivos" 'it seems that prostitution remains in the ellipsis' (Barrón Salido 1995, 9). ${ }^{4}$

Complicating this picture even further are the ambiguous attitudes reflected in commentaries by women working in prostitution--partly determined by the women's background, partly dependent upon her geographical location and her place in the class hierarchy of sex workers, partly coded with respect to the interlocutor (reader, client) and presumptions about his desires and expectations, partly dependent upon the space of utterance (whether published in a book, or interviewed in the work place, in their homes, in a clinic or other third location). For example, Mexico City sex worker Claudia Colimoro, president of an organization called Mujeres por la Salud en Acción contra las Enfermedades de Transmisión Sexual y el SIDA 
(Women for Health in Action against Sexually Transmitted Diseases and AIDS; MUSA, formed in 1985), presents a very different image of sex workers than that encoded in popular stereotypes. In contrast with the glamorous and terrible fatal woman image of "la dama del alba" ("the lady of the morning"; singer Víctor Manuel's code term for AIDS in a popular song) or the woman inappropriately attracted to sexual pleasure, Colimoro points out that $80 \%$ of Mexican female sex workers are mothers, a reality that "hace que las mujeres tengan que llevar una vida doble para satisfacer las necesidades de sus hijos y ocultar su ocupación y diciendo en su casa que trabajan de meseras o enfermeras" "forces women to live a double life in order to meet the needs of their children and hide their profession, by saying at home that they work as waitresses or nurses' (Ojeda 1994, 78). Colimoro's observation hints at a tense and often bitter renegotiation of accepted roles within the community, in which the prostitute and the saintly mother occupy the same social space, revisiting the home and the bar environments and rendering each more complicated. And yet, even Colimoro does not go far enough in her observation, since reference to a "double life" and "hiding their profession" suggests that the women in prostitution tend uniformly to accept the strictures of the dominant culture's moral rhetoric, which condemns them as immoral within the home space while covertly demanding their sexual availability within the various recognized zones of tolerance.

A somewhat different picture emerges from a large sample study of over 1600 female sex workers in six cities taken in 1987-88, in which researchers with la Secretaría de Salud (Ministry of Health) in one series of interview questions asked women working in prostitution about attitudes towards a variety of sexual practices. The women responded to a number of statements, and were asked to discriminate between what they found acceptable for themselves and acceptable for others. Clearly, these women know the codes of dominant cultural moral rhetoric; however, their own sense of appropriate behaviors do not always coincide with those norms. Evidence of this lack of fit between cultural mores can be observed in the results of the 
May 1988 interviews with 783 of these women. These responses elicit a picture of thesex worker's social context that is not strictly bound by dominant culture moral strictures, but instead looks a good deal more fluid. For instance, a very high percentage of the women agree with the statement that faithfulness to one's partner is a positive good both for themselves and for others (80\%/70\%; though about $1 / 3$ of the women interviewed also find nothing particularly reprehensible in extramarital relationships), yet there is an almost equally high agreement with the acceptability of the practice of receiving money in exchange for sexual favors both by themselves and others $(82 \% / 69 \%)$. Likewise, the almost 800 women interviewed also evince a surprisingly high approval rate with respect to society in general (42\%) for having sexual relations with strangers (Secretaría de Salud 1989, iv. 6-7). Just as we would be hesitant to draw conclusions from the Colimoro interview about the degree to which prostitute women share middle class norms, so too it seems relevant to withhold judgment about the very different narrative constructed in the Secretaría de Salud surveys. Reading the two side-by-side, however, reminds us of the degree to which questions that undergird much social/ethnographic/public health research--of good vs. bad information, or of research presumptions about reaching a single "truth" about the research subject--need to be complicated by the realization that such narratives (both the ones we implicitly create in the research paper and the ones provided us in interview responses) about women's lives are constructed in dialogue and situationally.

One factor contributing to the confusions about the status of prostitution in Mexico is that while prostitution is decried as an inescapable social evil, and prostitutes are considered both immoral and pathological, the act of selling one's body for money falls into a legislative gray area; not quite illegal, and more or less regulated depending on local policies and statutes. In the section of the Mexican penal code dealing with "los delitos contra la moral pública" 'Crimes against public morality,' the following are identified as criminal acts: "utrajes a la moral pública o a las buenas costumbres, corrupción de menores, lenocinio, provocación de un delito y apología de éste 
o de algún vicio" 'contempt of public morality or good customs, corruption of minors, procuring, inciting crime, and defense of this or another vice' (González de la Vega 1968, 304; Moreno 1968, 239). Thus, prostitution is technically legal, while houses of prostitution are outlawed under the prohibition against procuring. Despite this federal regulation, however, individual states have sometimes opted to legalize and regulate houses of prostitution in so-called "zonas de tolerancia" 'red light districts.' As Salazar González notes, these functioning state laws are in conflict with the federal code, and thus seem to be unconstitutional (Salazar González 1986; 99, 122). Likewise, as one state authority comments, "Que aún cuando la prostitución no está contemplada legislativamente como delito, no implica que los sujetos que a sus ejercico se dedican, lo tenga que hacer sin ninguna restricción" 'Even though prostitution is not legally defined as a crime, that does not imply that the subjects who dedicate themselves to its practice can do it without any restrictions' (CONASIDA, “Chiapas, Tuxtla Gutiérrez" 1995, 22). Because of the ambiguous legal status of prostitution, the continuing harassment of streetwalkers in most of the country is technically based not on the act of exchanging sex for money, but on the prostitute's personal appearance, for which she can legally be charged with "un atentado contra las buenas costumbres" 'assault on good customs' and can be held for thirty-six hours (Lamas 1993, 111). In the eyes of the dominant society as embodied in the national legal code, the prostitute then, embodies an immoral, but legal vice, a crime more against middle-class good taste than against the social order.

Perhaps because Tijuana has itself so often been stigmatized in centrist Mexican rhetoric as a whore of a city and a particularly loathsome blight on the national self-image, it serves as a natural locus for exploring the assumptions behind social and cultural codes and what these codes say about the form taken by investigation into sex work. From both sides of the border, Tijuana represents that tacky and vile and threatening thing that middle-class morality must resist, and cannot stop talking about. This contemporary image is deeply rooted in the city's volatile past. 
Tijuana's growth in the early part of the century had a good deal to do with the prevailing prohibitionist rhetoric in the United States. When Los Angeles prohibited bars and horse racing in 1911, the small Mexican town across the border received a sudden influx of bars, liquor stores, and night clubs. In 1916 the Hippodrome opened its gates, increasing the influx of tourists to the degree that by 1920 the United States attempted to control the movement by ordering the border closed between 6:00 pm and 8:00 am. With the new Agua Caliente Casino (1928), Tijuana's attractions for tourists increased dramatically. At the same time, the prevailing industries contributed to serious social problems on the border, exacerbated by the Great Depression of 1929. Murrieta and Hernández note: "El glamour de Hollywood se desplazó a Tijuana. Refugio de revolucionarios hostigados, de cristeros perseguidos por la ley, de trabajadores agrícolas expulsados de Estados Unidos por la crisis de 29 y de mexicanos que llegaban a poblarla, seducidos por su auge y lejanía” 'Hollywood glamour displaced itself to Tijuana. It was the refuge of harassed revolutionaries, of Cristeros pursued by the Law, of farm workers expelled from the United States by the crisis of 1929 and of Mexicans who arrived to populate it, seduced by its growth and distance' (Murrieta and Hernández 1991).

The "Black Legend" of Tijuana as a giant brothel for U.S. tourists, soldiers based in San Diego, and transient Mexicans on their way to California's prosperous agricultural fields makes the study of prostitution in this city both necessary, and exceptionally difficult. An additional complicating factor is the widespread disdain in Mexico's centralized power structure for any border issues. Carlos Monsiváis, for example, underlines the political, social, and cultural cost of the traditional division between Mexico City and the rest of the country: "Se sanctificó el juego de los opuestos: civilización y barbarie, capital y provincia, cultura y desolación. Desde principios de siglo ... cunde una idea: la provincia es 'irredimible', quedarse es condenarse" 'A play of opposites was sanctified: civilization and barbarism, capital and provinces, culture and desolation. Since the beginning of the century ... the idea has propagated that the province is 'unredeemable,' 
that to stay is to be condemned' (Monsiváis 1992, 197). From Mexico City's point of view, the northern border is imagined as perhaps the most "unredeemable" of all the provincial representations. It is from a centrist perspective the region most affected by the cultural, linguistic, and moral corruption of Mexico's unfortunately proximate and powerful neighbor, the United States.

In Tijuana there are estimated to be 15,000 women working in prostitution, on the street in some sectors, as well as in 210 night club/brothels. Clients include two large groups: tourists and visitors from the United States and, increasingly, other countries; and secondly, internal migrants from other states in Mexico (over 94\% of migrant workers are men, particularly concentrated in the age group of 25-34 years old). These women range in age from their twenties to their fifties, have been involved in prostitution for a period ranging from a few weeks to many years, and work in a variety of establishments ranging from the least exclusive to the more expensive venues. While family circumstances vary, most of the women indicate that they come from the countryside, often from situations of extreme poverty. Family violence (father beating the mother, parents beating the children) is common, and the women frequently seek to escape from the abusive home either by forming partnerships with young men at a very early age (often as young as thirteen or fourteen) or seeking work. They tend to fall into prostitution, which they may or may not drop in and out of over the years, from economic necessity propelled either by the failure of a relationship or by intolerable working conditions in other jobs. Some of the women are wholly independent; others have partners; most have children. Some of their children and partners know about their jobs; others do not. Their attitudes towards the sex industry vary widely, but most women indicate that they create certain boundaries within their work and insist upon specific practices that allow them to establish a comfort zone within the profession, while at the same time they point to the failure of other women in the same 
community of sex workers to do so--a commonly seen contributing factor to drug addiction and venereal disease.

A number of the women indicate that their first sexual experience was rape. One describes being kidnapped in a car by a young man she knew only by sight and being so injured by the rape that her attacker took fright and dropped her off at a hospital. Another describes being coerced into having sex when she was thirteen. A third describes an acquaintance rape by her employer:

Pues como fue tan frio, tan cruel. No me la vas a creer, pero ese señor después de violarme me pagó. Sí, me botó el dinero. Y yo lo necesitaba. Yo estaba estudiando en ese entonces en Hermosillo y trabajando y este señor era el gerente de la empresa, me ofreció raite y de ahí en lugar de ofrecerme un raite, y yo le acepté raite porque estaba lloviendo mucho, entonces, de ahí me llevó a un hotel. Así con todo lujo de violencia y prepotencia me metió a un cuarto a empujones hizo lo que quiso, todavía me amenazó, y pues. Nosotros habíamos sido de una condición no precisamente humilde, sino clase medio pero muy retraídas por mi mamá. Entonces, la educación que nos habían dado, ¿no? No fui capaz de reclamar ni nada de eso ¿no? Me sentía avergonzada, me sentía humillada, impotente. Y lo tomé con tranquilidad, no me podia quejar con nadie. Y ya después, pues seguí, seguí más o menos la misma ruta nomás que seguí cobrando.

How it was so cold, so cruel. You are not going to believe me, but that man after raping me he paid me. Yes, he threw money at me. And I needed it. I was studying in Hermosillo at that time and I was working and that man was the manager of the business. He offered me a ride and there instead of giving me a ride, well, I accepted the ride because it was raining hard, and then he took me to a hotel. There, with a lot of violence and superior strength he forced and shoved me into a room, did what he wanted to do, and even threatened me afterwards and then... We had come from a background that was not 
precisely poor, more like middle class, but very repressed by my mother. So the education that she had given us, well, I wasn't able to file a complaint about any of this, right? I felt ashamed, I felt humiliated, impotent. And I took it calmly, I couldn't complain to anyone. And afterwards, then I continued, I continued more or less down the same path only now I began charging.

This woman's story of rape by her employer is but a more violent form of the many stories of sexual harassment in the job place, confirming a widespread machista stereotype that unattached women are fair prey for sexual advances. As one of the interviewees says simply, she became a prostitute "porque no tengo estudio y cualquier parte que vaya el caso es lo mismo" "because I don't have any schooling and wherever I go it's the same story.' Another woman describes moving from job to job in order to avoid overfamiliarity on the part of male bosses, and expresses her frustration when it is assumed that a young widow with a child will be sexually available as one of the normal perks of the boss's job. Eventually, she concludes that there is no way to avoid being forced into sexual relations, so she decides to prostitute herself voluntarily, and for pay: "y resulta que al final de cuenta tienes que hacerlo ... y ya no tienes hasta donde libertad de hacer" 'and it turns out that you have to do it after all ... and you don't even have the freedom to do it.' Over and over again in these stories the women describe a societal structure based on male dominance in the workplace and male gender right over women who are perceived as stepping out of their traditional roles, first by remaining unattached to a male protector, and secondly by attempting to enter the realm of paid labor. The alternatives--to have sex with male coworkers or to constantly change jobs--are seen as increasingly unviable and unstable options.

The women freely admit that prostitution provides a better living than other unskilled labor, since a minimum wage job is not enough for them even to buy sufficient food to support themselves and their family, much less pay the rent. Furthermore, besides paying the food and rent, the relatively high wages earned in sex work allows for a certain discretionary income, and 
consequently a certain freedom. Thus, while many of the women indicate that circumstances forced them into sex work, because voluntarily or involuntarily it would become part of any job, the narrowing of employment options paradoxically offers certain advantages to the woman who is able to use the system to her benefit. The women can choose the number of days and number of hours in a day they work; they can choose the number of clients they attend and pick specific clients from among the men soliciting their services; they can save their money and leave prostitution entirely, or drop out for a period of time. Because sex work, while tension-wrought and exhausting, allows for this flexibility, several of the women describe holding other jobs in the informal economy as well as selling sexual favors; they talk about buying and selling items from the other side of the border, of working in shops, or selling foodstuffs.

A number of women see in prostitution the opportunity to live an independent life, in which they are no longer dependent upon an abusive, unreliable, or unfaithful partner. As one woman says, "no me gusta depender de nadie, ni que se posesionen de mi mente, de mi tiempo, de mi persona. No me gusta que me manejen por el hecho de estarme dando un cantidad a la semana o al mes" 'I don't like to depend on anyone, nor to have anyone own my mind, my time, my body. I don't like them to control me by the fact of giving me so much per week or per month.' Another woman says that she has come to Tijuana from her home in the countryside for a few months only, so as to earn the money to pay off a debt. Still another came out of retirement to pay for expenses inconsiderately incurred by her immediate former partner. Others are saving money to establish a small business, or to buy a truck. Yet another is working for a time because she wants to be able to give her children the kinds of presents she missed as a child. Several women indicate that they are the sole support of extended families including their own children, their parents, and the families of siblings, and that they work longer hours, or quit working for a time, depending on family necessity. As one woman among many notes, "no me gustaba al principio pero me hice la idea de que me tenía que gustar porque tenía que atender a mi mamá, a 
mi hermana y dos niños que tengo" 'I didn't like it at first but I told myself that I had to like it because I had to take care of my mother, my sister, and my two children.'

This attitude of looking for the positive side of an experience which otherwise would be very unpleasant is common to all the women interviewed. Importantly, the women in these interviews almost invariably describe themselves as exceptions to the general rule within the communities of sex workers, and indicate that their difference resides precisely in the attitude they bring to their work. Women who are egotistical or uncertain of their motives and goals, say the women interviewed, are the ones most likely to destroy themselves through substance abuse. Women like themselves, who are able to step outside their immediate environment and focus on the positive side of their jobs are the ones who survive, remain healthy, and have the intelligence to use the system against itself. Most important among the positive aspects are the rewards that accrue from seeing the family better itself; many of the women point with pride to how well their own children and their nieces and nephews have done, precisely because of the assistance that they have been able to provide: these are children with enough to eat, and decent clothes to wear, children who have finished high school, technical school, or even college. In this respect these interview responses are astonishingly consistent with the findings of therapist Clara Coria in her work with middle class women, suggesting the degree to which the Tijuanan sex workers interviewed have constructed themselves narratively in these dialogues according to models of good and bad motherhood, ironically finding support in and complicating a value structure that degrades them. Coria speaks of "fantasías de la prostitución" in her middle class clients (prostitution fantasies) that manifest themselves as "el pudor frente al dinero ... . Hablar de dinero 'impúdicamente' (sin pudor) sería como evocar una sexualidad prohibida" 'modesty about money.... To speak of money immodestly (without modesty) would be like evoking a prohibited sexuality' $(1986,45)$. To avoid association with this prostitution fantasy, says Coria, "las mujeres son capaces de posponer o renunciar a intereses personales para no hacerse pasibles 
de semejante estigma" "women are capable of postponing or renouncing personal interests so as not to suffer from this stigma' (74). The prostitute women interviewed here also divide money into good money (used for altruistic purposes like supporting family) and bad money (used for self-gratification, by women who consequently become prone to other vices such as drugs and alchohol), allowing them to distance themselves from the necessities of their work. Paradoxically, however, if we follow Coria's line of reasoning, the Tijuanan sex workers are finding strength in an ideological position that explicitly excludes them, suggesting how identities are bound up in cultural dictates.

At the same time, these women remind us that job need not be wholly unpleasant, thus breaking down the middle class prositution fantasy that associates desire, female sexuality, and money along quite different lines. In the dominant culture fantasy, a sex worker is less morally reprehensible if she suffers endlessly in her work, and more degenerate if she enjoys it; the good mother, or good money, could never be linked to transgressive sexuality and even less to the satisfaction of illicit desires. A number of the Tijuanan women comment that they find sexual satisfaction with their partners, particularly with repeat customers, or with men who treat them as human beings, with kindness and thoughtfulness. One woman even sees human development prospects within prostitution itself, when it is approached with the right attitude: "realmente es una escuela ... si se toma de una manera positiva. ... A mí me ha servido mucho en que he aprendido a valorar a la gente, a valorarme yo misma, a comprender, a entender, a investigar también" "it really is a school, ... if taken in a positive way. . I It's helped me a lot in that I have learned to value people, to value myself, to comprehend, to understand, and to investigate as well.'

The women interviewed do not lose sight of the ugly aspects of their lives, complicating once again the narrative being drawn by these women, and showing its inevitable cracks and inconsistencies. They freely recognize the potentiality for women to get lost if they are not strong 
enough to overcome the environment, which by its very nature is ugly and depressing. One woman describes how difficult it is to work on a daily basis, "hagas o no hagas el acto sexual" 'whether or not you do the sex act.' She explains: "es la tensión, es la desvelada, es el alcohol, es, aunque no fumes, ya estás fumando ..." 'it's the tension, it's the lack of sleep, it's the alcohol, it's, even if you don't smoke, you're smoking anyway ....' Another adds the stress of pretending to be happy and having to laugh when she least wants to laugh. Still another comments on the high degree of alcohol and drug use among the women: "A veces yo comprendo a las muchachas cuando yo las veo que se dan su pase de coca o de cristal y sus acá todos lo que traen. Yo las considero porque yo sé que tienen que aguantar a cualquiera, a cualquiera. Y para aguantar a cualquiera hay que, no hay que andar en sus cinco sentidos. Apenas tomándose unos tragos o la droga para que así pueda uno soportar a cualquier" 'Sometimes I understand the girls when I see them and they shoot up their coke or their rock or their whatever it is that they bring. I feel sorry for them because I know that they have to put up with everyone, with everyone. And to put up with everyone, you can't go around sober. Only by drinking a few glasses or with drugs can one survive it.' Indirectly, in this manner, the women talk about their own drug or alcohol problems, while they directly and specifically describe themselves as the exception to this general rule of exhaustion, violence, and substance abuse.

Frequently the women shift from first person to second or third person at crucial points in their narration, thus distancing themselves from a disagreeable personal experience. For example, in the quote that follows, the woman describes her experiences in the bar where she works in the second person, displacing and generalizing her experiences, while her comments on her home life are expressed in the first person:

$\mathrm{Y}$ va de todo, y tanto pues tienes que soportar un viejo borracho que anda hasta las mangas y te diga cosas y tienes que aguantarte porque estás ahí. No vas a darle una cachetada, pues no, ¿cómo te verías? todo el mundo te corre. Te aguantas y te quitas nada 
más del lugar.... Sales ya aquí, piensas, a respirar aire fresco. Es lo que te digo. Yo llego a la casa y quisiera ... pero como llego tan cansada, tan malhumorada, a veces fastidiada. Duermo, descanso y al día de mi descanso lo primero que hago, me levanto, me doy un regaderazo, y me voy a caminar al parque ....

All kinds go there, and so many that you have to put up with an old drunk who's falling all over himself and tells you things and you have to put up with it because you're there. You aren't going to slap his face, oh no, how would that look? everyone would throw you out. You put up with it and you just move from that spot.... You are getting out of here, you think, to breathe fresh air. That is what I am telling you. I arrive home and I wish ... but I arrive so tired, in such a bad mood, sometimes disgusted. I sleep, I rest, and on my day off the first thing I do is I get up, I take a shower, and I go for a walk in the park....

There is a certain poetry to this passage which falls so neatly into two parts. The second person narration of the first few sentences evokes a restricted space, where movement is limited, as are options for verbal responses to provocative remarks. In the bar, the woman feels dirtied and yearns for fresh air. The second half of the passage provides the counterpart to the first; here is the cleansing of body and soul; the shower, the walk in the park, the recuperation of the "I."

This division of the self in language--of the first person voice shifting to second or third person and back again--duplicates a common division in the essential spaces of the woman's life. Many of the women hide their real jobs from their families, telling them that they are waitresses in a restaurant, cashiers in a store, assembly plant workers, salespeople or street vendors, or that they clean houses, in some cases using a secondary source of income as a disguise for their primary one. Many sex workers, especially those with children, avoid the topic of their jobs with their families; as one woman says, "yo no les voy a dejar el trauma a mis hijos" 'I am not going 
to leave my children with that trauma.' More realistically, perhaps, as one woman says, it would be very difficult for their children not to guess what is going on at some point: "posiblemente cuando era niño pues lo podía engañar. Yo sé que hoy siendo él un adulto no lo voy a poder engañar porque en primer lugar una persona que no tiene un empleo, que es una mujer, que se ve más or menos físicamente y que trae mucho dinero en la bolsa y compra carro y hace esto y hace lo otro, pues es muy díficil de que alguien se la trague" "Maybe when he was a child I could fool him. I know that now that he is an adult I will not be able to fool him because in the first place a person who doesn't have a job, who is a woman, who is more or less good looking and who carries around a lot of money in her purse and buys a car and does this and that, well, it's difficult for someone to swallow.' Similarly, while extended families may receive a distanced and buffered version of the women's employment history, most of the women's long-term, live-in partners know about their girlfriend's profession, though considerations of "respect" make that profession an open secret that is not discussed. As one woman says specifically, in response to the question, "would you tell your son about your job?”: "No, porque yo sé que él lo tiene sobrentendido. Y si él guarda silencio es por respeto. Entonces, si yo hablo, ¿qué caso tiene?” 'No, because I know that he implicitly understands. And if he maintains silence, it is out of respect. Thus, if I speak, what purpose would it serve?' Here, the delicate dance of silenced mutual understanding creates a closer and more respectful relationship with her child, in which each of them respects implicit distances established by love and custom.

In any case, for most of these women the topic of their work is more or less taboo outside their working environment; whether out of shame, or concern about showing the children a bad example, or simply a kind of unspoken respect for privacy on their partner's and their children's part, the woman's profession remains unacknowledged. "A veces digo yo, no tiene por qué saber de mi vida cualquier persona.... Tengo muchas ... amistades pero no, muchas no saben ni la mitad de mi vida porque soy muy reservada" 'Sometimes I say, not just anyone 
has the right to know about my life.... I have many ... friends but, no, many don't know even half of my life because I am very reserved.' Once again, virtues valued by the dominant society-reserve, respect, caretaking--are reinscribed with a difference in the double life of the sex worker, where what is spoken and what remains unsaid, both at work and in the home, constitute the very warp and woof of her life.

This double-voiced silence around an open secret is not always the rule. One of the women interviewed indicates that in her family the relationship she has built with her children has allowed them to go beyond the tacit recognition of her profession, in which the mother's job becomes an unspoken matter of concern. The woman indicates that all her children know exactly what she does for a living, and that their support is extremely important to her in maintaining an integrated life. She argues reasonably that since her children know exactly what their mother is doing and why, they will never feel the betrayal or shame that afflict some families whose mothers try to maintain the secret of their real jobs. She also uses her life as an object lesson for her children on the values of education, and points proudly to the success her children have achieved in school. Likewise, another woman comments that her children have always known about her profession; however, now that her daughters are reaching the age of having boyfriends they have decided as a family that they do not want the boyfriends to know, for fear that it would lead to misinterpretations of explanations that could only be awkward.

While most of the women indicate that they prefer to keep the two halves of their lives completely separate, a common theme running through the interviews is the economic necessity of working in prostitution in order to support a family, and, in a parallel commentary, the importance of maintaining a focus on the family when working so as to preserve their health and self-respect. Thus, paradoxically, the same forces that propelled them into prostitution are the ones that give them the strength to survive its destructive aspects. Maternity, then, is both a precondition for many of these women, as well as the single most important factor in defining 
their sense of self. "Yo me dediqué por entero a mi hijo" "I dedicated myself entirely to my child," says one woman. Another adds, "Sea yo una prostituta, . . . siempre las tuve bien cuidadas" "I may be a prostutite, but my daughters were always well taken care of,' implicitly recognizing the dominant society prejudice that sees women working in prostitution as irresponsible and evil: the sinner or femme fatale stereotype. Another woman, whose children know that she works in prostitution, uses her own life as an object lesson in motivating her children to work hard at their studies. In reproducing one such conversation for the interviewer, she cites what she would tell her child: "yo no quiero que Ud. sea lo que yo soy. Si Ud. sabe que está mal lo que yo estoy haciendo por esto y esto otro, yo quiero que estudie y que Ud. sea muy diferente a mí' 'I don't want you to become what I am. If you know that what I am doing is wrong because of this or that, I want you to study so that you can be different from me.' In this instance, the woman marks out for the interviewer a clear distance between what she is (a responsible mother) and what she does (sells her body to pay for her children's education).

The responsible mother is not only valued as an absolute social good; she is perceived as a survival mechanism in the otherwise destructive world of the red zone. One example stands for many:

Pero he visto muchas mujeres que nada más se prostituyen para drogarse y ni siquiera se dan cuenta de como están sus hijos. Nos les importa su alimentación, ni estudio, ni nada. Nada más ellas se prostituyen para el beneficio de ellas, para satisfacer los deseos que ellas traen. Y eso es lo que a mí en la prostitución no me admira de nada. Simplemente uno se metió a esa clase de vida pues hay que sacarle provecho y cuidarse uno.

But I have seen a lot of women who just prostitute themselves for drugs and don't even notice their children. They don't worry about their food, their schools, or anything. 
They just prostitute themselves for their own benefit, to satisfy the desires that they carry around. And that is something about prostitution that I don't care for at all. Simply put, if one has gotten into that kind of life, one has to get the best out of it and take care of oneself.

The pathos evoked in these comments is too strong to be ignored. This woman eloquently defines the constraining qualities of a sex worker's life; in order to work in the dehumanizing world of the red zone, self respect and respect for others are the keys to survival. At the same time, to be able to function at all, the women must separate within themselves the roles of mother/caretaker and the sex worker. However, if the separation is too absolute, the woman falls prey to the dangers of the prostitute's world: the drugs, the egoism.

And yet, of course, the very process of interviewing brings together the two parts of the women's lives, and whether or not it is a consequence of the questionnaire, the resulting picture is strikingly consistent with other stories of professional women in other, more traditionally accepted venues. Overwhelmingly, stories about professional women--whether a Tijuana street prostitute or a prominent lawyer like Hillary Rodham Clinton--at some point place emphasis on the woman's concept of herself with respect to her home and her children: a feature generally elided in stories of professional men. It is assumed that a woman's identity is most clearly elucidated with respect to her home life, whereas a man's identity is consumed in his profession. This factor, with respect to the in-depth interviews of Tijuana women involved in sex work, and perhaps with respect to their real lives as well, allows them that most important distancing quality: for whatever good they see in their profession has to do with service to others, and it is the weak or the unwary who are consumed by the profession, and hence, destroyed.

We need also recall that for the women in prostitution, their work often occurs in a space which is not unambiguously illicit. Within the red zone, certain behaviors are accepted; outside of that particular space both clients and prostitutes enter into another set of social, familial, and 
sexual relationships that may or may not reflect very different expectations for male and female behavior. It is, says Angie Hart speaking of a Spanish red zone, precisely the permeability of the boundary between what is allowed and what is prohibited that makes the space of prostitution so titillating for clients: "Many clients . . . describe their presence in the barrio as 'vice.' However, they were able to enjoy this 'vice' in an atmosphere in which this was accepted as a leisure pursuit ..." (Hart 1995, 219). For both the men and the women, then, the relationships they establish within the red light district are ambiguously coded. For the men, it is a leisure activity, often imagined not as strictly evil, but in terms of playing at transgression, of practicing a "vice" imagined within ironic quotation marks; for the women it is a temporary and generally unpleasant job. If the clients sometimes express interest in crossing these limits between differently coded spaces--wanting home addresses or even begging to marry sex workers--it is the women themselves who make an effort to retain some separation in the two parts of their lives; rejecting overtures, only infrequently allowing men they have known as clients to become permanent members of their lives outside of their work.

In order to exert some control over their circumstances, these women describe techniques they employ to carve out a comfort zone for themselves in the midst of the tense, uncertain environment. One of the ways in which the women mark out boundaries within prostitution is by definition of specific practices which they use to create reserved spaces, often spaces on their bodies. Thus, all of the women interviewed insist that they require condom use of their clients, and uniformly, any of the women who admit to having caught a venereal disease at some time in their lives insist that it occurred outside of work, with a partner who was not a client, and with whom, hence, they were more careless about insisting upon safe sex practices. One of the women says that her only experience of sexually-transmitted disease dates from her youth, before beginning as a sex worker, when a boyfriend gave one to her, and she did not even realize why she was sick. Another woman comments that she was infected because she wanted a social life 
outside of work, one involving going out for dinner and to movies, and showing affection to a man. However, "los hombres andan sueltos como las mujeres de las maquiladoras" 'men run around loose like the women from the maquiladoras' and these contacts outside of the professional setting of prostitution to her mind cause all the problems because, unlike responsible sex workers, women and men who act promiscuously in an unprofessional manner tend to spread disease. Still another describes her disgust upon finding out that her partner has gonorrhea. She immediately had herself tested for the disease as well, and was able to prove exactly where the guilt lay when her test turned out negative. In response, she not only threw her erstwhile boyfriend out of her life on the spot, but refused to give him a ride home from the clinic in her car, "no, no, no, le dije, no vayas a dejar aquí microbios" ‘No, no, no, I told him, you aren't going to leave your microbes in here.' Once again, we take these stories to be not so much an accurate account of the relative safety from contagion within prostitution, but rather as modern mythologies, cautionary tales that reverse the dominant culture's myth of prostitution as a site of infection. In these stories, unlike the more familiar middle-class tales of the evil women who make men sick by passing on their vile female-associated diseases, it is the hypocritical dominant culture that victimizes sex workers, who are constantly alert to these persistent threats that derive from a contaminated space outside formal sex work. Certainly, this image of the knowledgable and professional sex worker holds true only for a certain subset of Tijuana prostitutes; at the same time, we are reminded that whatever fantasies the male clients may bring to their encounter with a prostitute, almost by definition the woman has far more experience than the man, thus offsetting whatever power differential may be encoded in patriarchial expectations and paid-sex relationships.

In an analogous manner, the women describe the specific sexual practices in which they engage with reference to a code that also sets boundaries indicating physical and mental reserve, or even a kind of patriotic pudor (modesty). When asked about sexual practices, the responses 
are surprisingly uniform: the women consistently indicate that they prefer "normal" vaginal sex. Some of them express ignorance about other sexual practices; some indicate that under special circumstances they will perform oral sex, albeit reluctantly; all vehemently deny that they ever agree to anal sex with a client. When the inquiry is made, one woman says she typically responds: “soy mujer, no maricón” 'I'm a woman, not a fag.' Another hints that such unnatural perversions could come only from foreigners or contagion by foreign practices: "Todavía soy muy mexicana, ¿verdad? Yo sexo anal no lo realizo por ningún concepto” 'I am still very Mexican, right? I don't perform anal sex under any circumstances.' Another indignantly responds to the inquiry about sexual practices other than vaginal sex: “¡Jamás! Te estoy diciendo que yo soy limpia en todo aspecto sexual. .... Nunca jamás en la vida permití que me hicieron cochinadas ni que me dijeran que yo tenía que hacerlo" ‘Never! I am telling you that I am clean in every sexual aspect.... I never ever in my life permitted anyone to do dirty things to me nor to tell me that I had to do it.' Still another describes her technique with insistent clients; she tells them, "mira, la verdad es que quiero llegar virgen de un lado de mi cuerpo para el día que yo me case. .." 'Look, the truth is that I want to arrive virgin on one side of my body for the day I get married ....'Again, what the women are marking with these comments is a certain comfortable social space, perhaps real, perhaps constructed in the imaginary exchanges of interview expectations. Clearly, demands for oral and anal sex are extremely common--as one woman interviewed in Mexico City by another researcher notes "me imagino que como la novia o su mujer no pueden vienen con una a ver si pega" 'I imagine that since the girlfriend or the wife can't, they come to one of us to see if they can talk us into it' (Aranda Luna 1990, 99)--what the Tijuanan women are signaling is a particular personal reserve, a chastity within prostitution that implicitly figures as one of the differentiating qualities separating these women interviewed from the mass of sex workers who are, perhaps, less stable, less moral, more prey to the destructive side of their jobs. Here too, discretely, the sex workers are indirectly addressing the concerns of 
the dominant culture about the prostitute as a site of infection, in that many of them are aware that AIDS is associated particularly with homosexuals and with anal sex.

Condom use is one of the most contested problems in establishing the ground rules for a sexual relationship between a woman and her client. While Marta Lamas's study of street prostitution in Mexico City arrives at the conclusion that "ninguna chica se niega a hacerlo sin condón, pues eso representa perder al cliente" "no girl would refuse to do it without a condom, since that would mean losing the client' (Lamas 1993,123), ${ }^{5}$ the Tijuanan women interviewed are far more united and adamant about condom use, to the degree that one of the more common topics of conversation involved an exchange of stories and suggestions of methods to convince reluctant clients. As one of the women notes, it is important to have an unbreakable agreement among the women that they will only accept clients with condoms since, as she says, $99 \%$ of the men try to get out of using one: "vamos a suponer que yo aceptara irme con un cliente sin condón, al ratito ya le gustó otra y también sin condón. Y es donde va el contagie" 'let's suppose that I agreed to go with a client without a condom, and then after a while he likes another woman and also without a condom. And that is where contagions start.' One of the more common arguments is to say that the sex worker knows she is disease-free because of her regular checkups, but that the client can give no such assurances; this argument has the benefit of reinforcing the message that the professional sex worker offers advantages to a man careful of his health and that the red zone is a safer environment for non-monogamous men than the larger community. The alternative argument is also common: that the client may believe he is disease-free, but since he cannot have the same confidence about his partner, condom use is in his best interests.

The national Informe técnico indicates that $95 \%$ of the sex workers surveyed feel that prostitutes should use condoms (Secretaría de Salud 1989, vi.4), that $57 \%$ of them have used condoms in the nine months previous to the study (Secretaría de Salud 1989, vi.8), and that approximately $15 \%$ use them at all times (Secretaría de Salud 1989, vi.11). Obviously, the 
responses of the women interviewed in depth in Tijuana, in their uniform insistence on their unwavering commitment to consistent condom use with their clients, do not accord with the national statistics. Both Hernández Avila and Uribe-Salas remind us that questions about condom use are particularly loaded ones, and that the responses need to be evaluated with respect to behavioral, social, and political contexts (Hernández Avila 1991, 185, 187-88; Uribe-Salas 1996, 124). ${ }^{5}$ We do not attempt to resolve the question of whether the women are lying or not, but would like to point out in evaluating these responses merely that these women's awareness of the importance of condom use indicates an consciousness of the issues involved in safe sex practices and serves implicitly to define two important ideological spaces: (1) of the woman interviewed as wholesome and intelligent, (2) of the space of prostitution as an infection-free site where knowledge is put into practice, in contrast to the less professional, less careful practices of the general population. Once again, comments about consistent condom use help to create certain limits and boundaries within the sex worker's environment, and to confirm her self worth.

What is most powerful in these interviews is the glimpse they permit us into the lives of these women, as women, neither symbols of evil, metaphors of disease, or displaced representatives of a narrative style. Their stories speak to the pervasive silence around the image of the woman working in prostitution in modern Mexico, and open up an new space for continued study. Over and over again, in these interviews with Tijuana prostitutes we are brought up short by the need to understand the dynamics of the interview process itself, in which, inevitably a narrative about the self is constructed in dialogue and situationally. Zalduondo et al remind us an understanding of the social context of paid sex requires the perspectives of clients, pimps and bar owners, rooming house owners, and police and other authorities (Zalduondo 1991, 173). Likewise, a fuller social characterization of the sex worker would include, minimally, the perspective of her family. By focusing on the sex worker as a deviant or marginal member of society, commentators greatly undercomplicate a very complex issue which cuts directly to the 
heart of how men perceive women and how women perceive themselves in variously different adumbrated social and narrative interactions. Even with respect to the degree that the sex worker's livelihood "depends on the maintenance of the very ideology which degrades her an makes her into a social outcast" (Davidson 1995, 9), her liminal status in society casts a strong light on questions of the social construction of gender, and on issues of control and consent in human relationships.

James Clifford describes the predicament of postcolonial ethnography as an unnerving process of negotiating across resistances while at the same time dealing with the moral tensions, inherent violence, and tactical dissimulations of modern fieldwork. His comments seem apposite to way we undertake a study of marginal persons in society as well :

Some "authentic encounter," in Geertz's phrase, seems a prerequisite for intensive research; but initiatory claims to speak as a knowledgeable insider revealing essential cultural truths are no longer credible. Fieldwork ... must be seen as a historically contingent, unruly dialogic encounter involving to some degree both conflict and collaboration in the production of texts. Ethnographers seem to be condemned to strive for true encounter while simultaneously recognizing the political, ethical, and personal cross-purposes that undermine any transmission of intercultural knowledge. (Clifford $1988,90)$

Existing scholarship on sex workers in Mexico does not well reflect the complexities of social practice nor does it explore the relationship to these women's complex sense of self, in which personal identity is reconstructed according to an awareness of the multiple spaces they inhabit. To take a single example from among many: Marta Lamas's article, informed by international feminism and published in her prestigious journal, Debate feminista, frames a discussion of street prostitution in two areas of Mexico City--Cuauhtémoc and Miguel Hidalgo--through a debate on symbolic violence and stigmatized behaviors. For a number of researchers involved directly in the 
field, this study has been particularly unfortunate with respect to its potential and actual consequences, because of its author's privileged location in Mexican society and Mexican government circles, and because the journal's international reception guarantees the article a certain influence. In a trenchant critique of Lamas's work, Armando Rosas Solis of the Universidad Autónoma de Baja California writes: "El artículo tiene una estructura poco clara ya que salta de una presentación de tipo moralista, sin especificar si ésta se refiere al contexto mexicano o internacional, para ligarla inmediatamente al contexto laboral y de ahí al político, para enlazarlo al movimiento de organización internacional de las prostitutas, para terminar con una serie de aseveraciones, que según se interpreten ... son muy aventuradas. ... En todo el texto se ayuda de citas para hacer propuestas y un analísis de sus sentimientos hacia Claudia [una trabajadora sexual] no hacia la prostitución ..." 'The article has a very unclear structure, since it leaps from a moralistic presentation, without specifying whether it refers to the Mexican or the international context, connecting it immediately to the context of labor and from there to politics, in order to tie in the international prostitutes' movement, concluding with a series of statements which, depending on how they are interpreted, are very risky.... The whole of the text depends on quotes to make proposals, and on the analysis of her feelings towards Claudia [a sex worker who assisted in the project] and not about prostitution' (Rosas Solis 1996). Lamas's article, then, purports to offer a new perspective on female prostitution based upon the author's experience with government-sponsored research groups and confirmed by her own participant observer status in the prostitutes' community. Most significantly, however, as Rosas Solis comments, her work remains structured by the moral codes it decries, unconsciously speaking to the stereotypes that derive from a particular class location.

Lamas recognizes her own pre-existing prejudices and discusses in the article how these biases were dissipated through her work with women in prostitution. She concludes the article with a call for more equitable treatment: "Una lucha por establecer mejores condiciones sociales 
tiene que incluir la tarea de desconstruir esta simbolización de las prostitutas como el mal o el pecado, tan ligada al pensamiento religioso y tan lejana de aspiraciones democráticas y libertarias" 'A struggle to establish better social conditions has to include the task of deconstructing this symbolization of prostitutes as evil or sin, so linked to religious thought and so far from libertarian and democratic aspirations' (Lamas 1993, 132). In his commentary on this work, Rosas Solis marks precisely how this conclusion demonstrates that Lamas does not in fact deconstruct the model describing women as either decent or whores, but rather reinstates the stereotypes her rhetoric apparently rejects, in that her work asks not for a more nuanced understanding of the multiples roles and spaces occupied by sex workers in Mexico, but rather for a revision of the dominant class's symbolic structure for appropriating the image of women in prostitution. In other words, the discussion that Lamas promotes remains within a single moral horizon and does not recognize alternative structures in which the figure of the prostitute interpolates herself--or is interpolated--on terms other than evil / not evil. This negative typing of the prostitute suggests to Rosas Solis that Lamas has a theoretical/structural stake in maintaining a discussion of prostitution in terms of marginality and stigma; her perspective, despite her six months of field work on the Mexico City streets, remains that of her upper class background rather than taking into account in a more than anecdotal way the perspective of the women who work within the very different class structures of prostitution.

The difference of opinion between Lamas and Rosas Solis has important material effects on how the studies of prostitution in the Mexican context are conducted and by whom. In Mexico, where competition for scarce resources is often fierce, and where the different regions of the country vary widely, current research has tended to be so narrowly focused that the results are not useful in reaching generalizations of wider import, nor have they been able to influence public policy at a national level. Furthermore, prostitution has seldom been studied as a social phenomenon in itself at any level, creating a knowledge vacuum about a population that, with the 
appearance of AIDS, has recently come under greater scrutiny. More nuanced studies that address the concrete social realities of men and women working in prostitution will require a shift of focus and of resources. Rosas Solis's cautionary words are apposite: “mis apreciaciones no son absolutas. Algunas de ellas deberán profundizarse, otras deberán de reformularse y otras deberán de fundamentarse con la realización de investigación en campo, pero definitivamente no se pueden dejar de considerar" 'my comments are not absolute. Some will have to be explored, others will have to reformulated and others will need to be established through field work, but definitively they cannot be brushed aside.'

What then, finally, can we say about the perspective of the prostitute apart from how she frames her life story for consumption by the privileged classes, whether in the form of a testimonio or a research interview? With respect to the familiar stereotypes, Rosas Solis--who draws from personal experience and from professional interviews with hundreds of sex workers in more than two dozen Mexican cities in seventeen states over a period of thirty years--suggests that:

El simbolizar a las prostitutas como el mal, el pecado o la escoria social, no es algo que esté dirigido a las mujeres que tienen este oficio.... Se da para las mujeres que no siendo prostitutas se dedican al goce sexual.... Por otro lado, este simbolismo, que tanto preocupa a los investigadores sociales, tiene sin cuidado a la mayoría de las mujeres que se dedican a la prostitución.

El otro simbolismo ... de que la prostitución es un trabajo como cualquier otro, es por mucho algo que tampoco les preocupa....

El problema de la prostitución no se debe de enfocar desde el punto de vista de demanda por parte de los hombres .... El problema se debe de abordar desde el punto de vista de la educación, familiar, escolar, de influencia del medio social, los cuales 
determinan las conductas y estereotipos a seguir, en estos radica la creación de necesidades y por lo tanto se da forma para que ésta se convierta en negocio. . . .

Symbolizing prostitutes as evil, sin, or social trash is not something directed towards women who hold this job. ... It is used for women who are not prostitutes and who are interested in sexual pleasure. ... On the other hand, this symbolism, which so worries social scientists, does not bother the majority of the women who work in prostitution.

The other symbolism ... of prostitution as a job like any other, is something that most of the time doesn't worry them either.

The problem of prostitution should not be focused from the point of view of male demand. ... The problem should be addressed from the point of view of education in families and in schools, of the influence of the social setting; these things determine conduct and the stereotypes people follow; from these derive the creation of necessity, and for this reason opens the space for it to become a business.

Rosas Solis points to the curious fact that it is within so-called "decent" society that women are excoriated for showing evidence of sexual desires. Thus, if a woman comes from a class background and upbringing that would seem to locate her within the category of "decent women," she may be stigmatized with the hurtful epitaph of "whore" if she behaves in a manner understood within her social context as overly sensual/sexual. At the same time, within the social space of the prostitute's community, such accusations would be irrelevant; it is only with relation to the stigmatized and abjected female other that the insults acquire their force. Again and again, we are reminded of the situational quality of our own work, its realignment of fantasies permeating the social imaginary in which the prostitute or her metaphors stand for whatever corrupting, dangerous quality needs to be expelled from society at a given time, and for whatever 
necessary betrayals hasten back to menace society with corruption. In this paper we have begun the project of disentangling and interrogating these social forms; in future work we hope to be able to more fully address psychological, economic, and demographic factors involving women working in prostitution, and to propose specific public health opportunities that go beyond testing and treatment of sexually-transmitted diseases. 
Basic Bibliography/Works Cited

Aranda, Clara Eugenia. 1976. La mujer: Explotación, lucha, liberación. Mexico: Editorial Nuestro Tiempo.

Aranda Luna, Javier. 1990. "Una también es gente." In Bellinghausen. El nuevo arte: 99-106.

Arreola, Daniel D. and James R. Curtis. 1993. The Mexican Border Cities: Landscape Anatomy and Place Personality. Tucson: U of Arizona P.

Barrón Salido, Patricia. 1995. Las "María Magdalena": El oficio de la prostitución y su estrategía colectiva de vida. Bachelor's thesis. Tijuana: Colegio de la Frontera Norte.

Bartra, Eli, et al. 1983. La Revuelta: Reflexiones, testimonios y reportajes de mujeres en México, 1975-1983. Mexico: Martín Casillas Editores.

Bellinghausen, Hermann, ed. 1990. El nuevo arte de amar: Usos y costumbres sexuales en México. Mexico: Cal y Arena.

Bersani, Leo. 1988. "Is the Rectum a Grave?" In AIDS: Cultural Analysis, Cultural Activism. Ed. Douglas Crimp. Cambridge, Mass: MIT Press.

Blanco, José Joaquín. 1988. Cuando todas las chamacas se pusieron medias nylon (y otras crónicas). Mexico: Joan Boldó i Climent.

-... 1981. Función de medianoche: ensayos de literatura cotidiana. Mexico: Ediciones Era. Careaga, Gabriel. 1990. Mitos y fantasías de la clase media en México. Mexico: Cal y Arena. 1992. La ciudad enmascarada. Mexico: Cal y Arena.

Chancer, Lynn Sharon. 1993. "Prostitution, Feminist Theory, Ambivalence: Notes from the Sociological Underground." Social Text 37: 143-171. 
Clifford, James. 1988. The Predicament of Culture: Twentieth Century Ethnography, Literature, and Art. Cambridge: Harvard UP.

Códigos penal y de procedimientos penales para el D. y T.F. y federal de procedimientos penales. 1964. Puebla: Editorial Cajica.

CONASIDA (Consejo Nacional para la Prevención y Control del SIDA). 1995. "Análisis de la situación de Ciudad Hidalgo, Chiapas." Internal technical report.

1995. "Resultados del análisis de la situación y propuesta para desarrollar una intervención para aumentar la seguridad del sexo comercial, en Chiapas, area de Tuxtla Gutiérrez." Internal technical report.

Coria, Clara. 1986. El sexo oculto del dinero: Formas de dependencia femenina. Grupo Editor Latinoamericano.

Davidson, Julia O'Connell. 1995. "The Anatomy of 'Free Choice” Prostitution.” Gender. Work and Organization. 2.1 (1995): 1-10.

De la Rosa, Martín. 1985. Marginalidad en Tijuana. Tijuana: Cuadernos CEFNOMEX.

Del Campo, Xorge. 1974. La prostitución en México. Mexico: Editores Asociados.

Espinosa Damián, Gisela. 1987. "Feminism and Social Struggle in Mexico." In Third World-Second Sex. Ed. Miranda Davies. London: Zed: 31-41.

French, William E. 1992. "Prostitutes and Guardian Angels: Women, Work, and the Family in Porfirian Mexico." Hispanic American Historical Review 72: 529-53.

Gamboa, Federico. 1903. Santa. Mexico: Fontamara.

García García, María de Lourdes, et al. 1995. Enfermedades de transmisión sexual y SIDA.

Mexico: Secretaría de Salud, Instituto nacional de diagnóstico.

García Jiménez, Marcelino. 1987. Breve estudio sobre la prostitución en México. Law thesis.Tijuana: Universidad Autónoma de Baja California. 
Gomezjara, F., et al. 1978. Sociología de la prostitución. Mexico: Ediciones Nueva Sociología. González de la Vega, Francisco. 1968. Derecho penal en México: Los delitos. Mexico: Porrua. González Rodríguez, Sergio, ed. 1993. Los amorosos: Relatos eróticos mexicanos. Mexico: Cal y Arena.

----. 1989. Los bajos fondos: El antro, la bohemia y el café. Mexico: Cal y Arena.

Hart, Angie. 1995. “(Re)constructing a Spanish Red-Light District: Prostitution, Space, and Power." In Mapping Desire: Geographies of Sexualities. Eds. David Bell and Gill Valentine. New York: Routledge: 214-228.

Hernández Avila, Mauricio, Patricia Uribe Zúñiga, and Barbara O. de Zalduondo. 1991. "Diversity in Commercial Sex Work Systems: Preliminary Findings from Mexico City and Their Implications for AIDS Interventions" In AIDS and Women's Reproductive Health. L.C. Chen, ed. New York: Plenum: 179-194.

“La industria sexual mexicana." 1994. Special section. Nexos 17.203 (November).

Juárez-Figueroa, Luis Alfredo, Mauricio Hernández-Avila, Patricia Uribe-Zúñiga, George Smulian. 1993. "Prevalencia de anticuerpos contra Pneumocystis carinii en sujetos con prácticas de alto riesgo de SIDA.” Rev.Inv. Clin. 45: 229-31.

Lamas, Marta. 1993. "El fulgor de noche: algunos aspectos de la prostitución callejera en la ciudad de Mexico." Debate Femenista 8: 103-133.

Lara y Pardo, Luis. 1908. La prostitución en México. Mexico: Librería de la Vda. de Charles Bouret.

Macías, Anna. 1982. Against All Odds: The Feminist Movement in Mexico to 1940. Westport, CT: Greenwood.

Martínez Baños, Roberto, Patricia Trejo de Zepeda, and Edilberto Soto Angli. 1973. Virginidad y machismo en México. Mexico: Posada. 
Maytrajt, Miguel and Mirta Arbetman. 1990. "La condición de la mujer, el proceso de trabajo y la salud mental." Fem 14 (February): 15-24.

McClintock, Anne. 1993. "Sex Workers and Sex Work: Introduction." Social Text 37: 1-10.

Monsiváis, Carlos. 1977. Amor perdido. Mexico: Era.

-------. 1981., Escenas de pudor y liviandad. Mexico: Grijalbo.

1992. "De la cultura mexicana en vísperas del TLC." In La educación y la cultura ante el

Tratado de Libre Comercio. Julio López, et al. eds. Mexico: Nueva Imagen: 189-209.

--------. 1980. "La mujer en la cultura mexicana." In Mujer y sociedad en América latina. Ed.

Lucía Guerra-Cunningham. Irvine, Cal: Editorial del Pacífico: 101-117.

Mora, Antonia. 1972. Del oficio. Prologue by María Luisa Mendoza. Mexico: Editorial Samo.

Moreno, Antonio de P. 1968. Curso de derecho penal mexicano. Mexico: Porrua,.

Muñuzuri, Eduardo. 1967. Memorias de "La Bandida." Mexico: Costa-Amic.

Murrieta, Mayo and Alberto Hernández. 1991. "Puente México: la vecindad de Tijuana con

California." Working paper, Colegio de la Frontera.

Ojeda, Néstor L. 1994. "Prostitución en los noventa." Nexos 17.203 (November): 76-80.

Pacheco Ladrón de Guevara, Lourdes C. 1988. "Haz conmigo lo que quieras: la prostitución

urbana en Nayarit." In Mujeres y sociedad: salario, hogar y acción social en el occidente de

México. Eds. Luisa Gabayet, et al. Mexico: Colegio de Mexico: 125-140.

Pheterson, Gail. 1990. “The Category 'Prostitute' in Scientific Inquiry.” Journal of Sex

Research 27.3: 397-407.

Poniatowska, Elena. 1988. "Xaviera Hollander o las glorias de la prostitución." In Fem: Diez años de periodismo feminista. Mexico: Planeta: 74-78.

Posada García, Miriam. 1995. "Prostitución: del engaño al abuso cotidiano." La Jornada July 25.

Quijada, Osvaldo A. 1977. Comportamiento Sexual en México: El hombre. Mexico: Tinta Libre. 
Rivera, George Jr., Hugo Vicente-Ralde, and Aileen F. Lucero. 1992. "Knowledge about AIDS among Mexican Prostitutes.” Sociology and Social Research 76.2: 74-80.

Rosas Solis, Armando. 1996. "Comentarios." Manuscript response to Lamas's article, cited with permission.

Sacks, Valerie. 1996. "Women and AIDS: An Analysis of Media Misrepresentation." Social Science and Medicine 42.1: 59-73.

Salazar González, José Guadalupe. 1986. Reglamentación del trabajo de las mujeres en los centros nocturnos. Law thesis. Tijuana: Universidad Autónoma de Baja California.

Secretaría de Salud. 1989. Informe técnico. Evaluación del impacto de la estrategía educativa para la prevención del SIDA en México 1987-88. Five volumes: Mujeres dedicadas a la prostitución, Hombres homo-bisexuales, Estudiantes universitarios, Personal de salud, and Público general. Mexico.

Stern, Steve J. 1995. The Secret History of Gender: Women, Men, and Power in Late Colonial Mexico. Chapel Hill: U of North Carolina P.

Toledo, Martín. 1981. El drama de la prostitución: Las que nacieron para perder. Mexico: Editores Mexicanos Unidos.

Uribe, Patricia, et al. 1996. "Prostitución en México." In Mujer: Sexualidad y salud reproductiva en México Eds. Ana Langer and Kathryn Tolbert. New York: World Health Organization; the Population Council and EDAMEX: 179-206.

Uribe-Salas, Felipe, et al. 1996. "Prevalence, Incidence, and Determinants of Syphilis in Female Commercial Sex Workers in Mexico City." Sexually-Transmitted Diseases. March-April: 120-26.

Vargas, Ana, compiler. 1986. La casa de cita: Mexican Photographs from the Belle Epoque. London: Quartet Books. 
Zalduondo, Barbara O. de, Mauricio Hernández Avila, Patricia Uribe Zúñiga. 1991. "Intervention Research Needs for AIDS Prevention Among Commercial Sex Workers and their Clients." In AIDS and Women's Reproductive Health. New York: Plenum: 165-177. Zenteno, Alejandro. 1996. “3,000 mexicanas vendidas en Japón.” Unomasuno 3 May: 1, 16. 


\section{Notes}

${ }^{1}$ A note will appear here acknowledging sources of research support. It was eliminated in this submission to retain anonymity.

${ }^{2}$ This issue is also addressed by Wendy Chapkis in her 1995 paper, “Too Close for Comfort: Prostitution, Participant Observation, and Sexual Stigma," in which she responds to the same theoretical/methodological problem posed by Chancer with respect to participant observation research in California and in Amsterdam. Chapkis' work has been further developed in her forthcoming book, Performing Live Sex Acts (Routledge). We thank Signs' anonymous reviewer for bringing this important work to our attention.

${ }^{3}$ In addition to these studies, Patricia Barrón Salido has done fieldwork during 1995-96 for her bachelor's thesis on an organized group of Tijuanan street prostitutes, the "María Magdalenas" and she has recently finished her Master's thesis, focused on the social reproduction of the families of prostitute women, in which Barrón's particular interest is the double stigmatization in their lives. Both these projects were completed under the direction of (name omited to retain anonymity).

${ }^{4}$ See bibliography at the end of the paper for references to specific works.

${ }^{4}$ Barrón Salido is referring to a specific report on the situation in Tijuana. She quotes Martín de la Rosa's extensive list of marginal persons: "Vamos a ocuparnos en este apartado de los peones, los albañiles, meseros, lavacoches, periodiqueros, las 'marías,' los que 'ya volvieron del otro lado' (metedólares), los que 'quieren ir al otro lado,' las empleadas domésticas, las 'que lavan ajeno,' los yonkeros, los 'cholos,' los barrenderos, los artesanos, los vendedores ambulantes, ... los desocupados" 'We are going to concern 
ourselves in this report with the peons, the construction workers, the waiters, the car washers, the newspaper sellers, the indigenous women workers, those who came back from the other side, those who want to go to the other side, the servants, the washerwomen, the junkies, the gang members, the street sweepers, the handicraft makers, the street salespeople, the unemployed.'

${ }^{5}$ Llamas's conclusion is also consistent with other local studies, though not with the statements made by the women interviewed in depth for the Tijuana study. For example, the CONASIDA report on sex workers in the area of Tuxtla Gutiérrez in the south of Mexico indicates that women in that area "no realizan en su práctica diaria negociaciones para utilizar el condón, la experiencia parece ser poca. Reiteran un rechazo hacia el uso del condón en casi todo tipo de cliente, con excepción de 'los hijos de riquillos"” 'they do not include negotiations about condom use as part of their daily practice, and their experience is slight. They reiterate a rejection of condom use in almost all types of clients, except "rich boys"' (13). Similarly, clients interviewed in Ciudad Hidalgo, also in the south of Mexico, tell interviewers that in that city the reported condom use by sex workers is much higher than actual condom use by clients (19), and women in Jalisco complain that while they are aware of the health risk, they are unable to use condoms because their clients refuse (Rivera et al 1992,77).

${ }^{5} \mathrm{An}$ important factor to remember with respect to condom use is that there are significant differences in the prevalence of HIV infection in the major Mexican cities, though high condom use does not correlate with cities in which there is a high risk of infection. One explanation for the the relatively high reported condom use rate in Tijuana would be the effectiveness of the education and prevention programs, particularly among the client base in southern Calfornia cities. 